\title{
AN ANALYSIS ON EDUCATIONAL QUALIFICATION PRESENTATIONS OF THE JOB SEEKERS IN THE LABOR MARKETS
}

\section{Yalçın Özdemir * Nurettin Beltekin $* *$}

\begin{abstract}
The purpose of this study is to analyze the presentation of educational qualifications in job seeking behavior. The study is based on the resumes uploaded on e-job search portals. In the study, a total of 114 resumes belonging to individuals who were seeking jobs in the informatics, industry and service sectors was examined. The data obtained from the resumes were analyzed with content analysis. As a result of the study, it is argued that the theory of human capital, which establishes a linear relationship between education and employment, is insufficient to explain the relationship between education and employment, and at the same time has an ideological function by separating employment from social context.
\end{abstract}

Keywords: educational qualifications, labor markets, employment, job seeking behavior, human capital theory

\section{INTRODUCTION}

Factors such as rising costs and falling profit rates in the national markets have resulted in capitalism reshaping itself to overcome these challenges. As Schumpeter1 stated, capitalism has continued under a new form by dismantling its old form with its creative destruction characteristic. One of the most important areas changed by this process, which is defined as globalization, is the structure of the production process and the changes in the business organization. In this new form of capitalism, uncertainties and complications have increased and a more dynamic-chaotic economic process has taken place. In today's capitalist formation, individuals had to equip themselves with more qualifications than ever before in a labor market that is less known and predictable compared to previous periods in order to sell their workforce power, or to make their existing qualities more visible to the buyers. In this context, in today's labor market, it is stated that there is a need for highly qualified human resource who can adapt to change and transformation in the economic structure, who has problem-solving and communication skills, and who has basic professional knowledge and skills2.

Article Types/Makale Türü: Research Article/Araştırma Makalesi

Received/ Makale Geliş Tarihi: 20.08.2019, Accepted / Kabul Tarihi: 26.11.2019

Doi: 10.26791/sarkiat.607413

* Dr. Öğr. Üyesi, Niğde Ömer Halisdemir Üniversitesi, yalosdemir@gmail.com

ORCID ID: https://0000-0003-3992-1360

** Dr. Öğr. Üyesi, Mardin Artuklu Üniversitesi, nbeltekin@yahoo.com

ORCID ID: https://0000-0001-6121-2849

1 Joseph A. Schumpeter, Capitalism, Socialism and Democracy (London: Routledge, 2010)

2 National Employment Strategy (UIS), "National Employment Strategy" (Retrieved May 22, 2018) 
One of the most important indicators to observe changes in new production structure and business organization is the numerical increase in the sector and its sub-sectors. According to data from the Ministry of Development3, while the number of sub-sectors that invested in the agricultural sector in Turkey was only seven in 1963, this number increased to 35 in 2009. Similarly, while only a few sub-sectors were invested in the energy sector in the 1960s, today the number of energy sub-sectors is in tens. In addition, while education and health areas were not considered as sectors in the 1960s, today they are seen as sectors, and their sub-sectors are gradually increasing. The sector lists approved by the Turkish Vocational Qualifications Authority4 includes Justice and Security, Information Technology, Glass, Cement and Soil, Environment, Education, Electric and Electronics, Energy, Finance, Food, Construction, Business and Management, Wood Works, Paper \& Paper Products, Culture, Art and Design, Mine, Media, Communication and Publishing, Metal, Automotive, Health and Social Services, Sports and Recreation Agriculture, Hunting and Fishing, Chemicals-Petroleum-Rubber and Plastics, Textile, Ready-To-Wear Apparel, Leather, Trade (Sales and Marketing), Social and Personal Services, Tourism-Accommodation-Food and Beverage Services, Transportation, Logistics and Communications.

With the term sector, Turkish Vocational Qualifications Authority refers to the European Qualifications Framework credentials document sectoral qualifications. The term sector is used to define categories or cross/horizontal vocational categories (IT, marketing, banking, etc.) where the companies' own economic activities, products or technologies (chemistry, tourism, etc.) are taken as the basis. As seen in the list, the new global economic structure is quite different from the traditional economic structure, consists of only three sectors (agriculture, industry and service). The number of economic sectors increased from three to 26. Undoubtedly, considering the fact that there are dozens of jobs found in each sector, it is obvious that there are hundreds or even thousands of jobs in a sector.

The theories of economics of education have analyzed the labor markets by examining issues such as productivity, employment, income and economic growth. Human Capital Theory (HCT), which is one of the most influential theories of educational economics, shares the basic assumptions of neoclassical economics. One of the best statements that explain HCT for Psacharopoulos5 is "Today's effort for education will return as a reward tomorrow". According to HCT, individuals are trained to increase their labor force qualifications, make themselves qualified and thus receive better jobs and better income in the future. In other words, HCT establishes a linear relationship between education and labor productivity and employment. On the other hand, according to the Screening Hypothesis, education does not increase the productivity of individuals, it only helps employers as an indicator of certain skills or qualifications of people through educational credentials6. Thus, according to this hypothesis, education classifies individuals with different abilities through diplomas-certificates /credentials which are considered as indicators of these abilities and thus helps employers to easily find the employees with the qualifications they are looking for. The Queue Hypothesis, on the

\footnotetext{
3 Ministry of Development, "Public Investments -Sector And Sub Sector Distribution" (Retrieved December 12, 2018)

4 Turkish Vocational Qualifications Authority. "Sector List" (Retrieved January 18, 2019)

5 Psacharopoulos, George, "İnsan Sermayesi Kuramı Üzerine Kavramlar ve Karmaşalar”, (Translator: Pervin Nadim). M.Ü. Atatürk Eğitim Fakültesi Eğitim Bilimleri Dergisi. 6 (1994),217-221. 6 L.Işı1 Ünal, Ë̆itim ve Yetiştirme Ekonomisi. (Ankara: Epar Yayınları, 1996), 98.
} 
other hand, argues that productivity is not about individuals, but about the qualifications of the job, such as capital structure and technology of the jobs7. And easier trainable individuals are located at the head of the queue of individuals who want to be employed in the labor market with their educational documents. As can be seen, the relationship between educational credentials and personal productivity is gradually reduced. In this context, theories of economics of education provide different explanations about the role of educational qualifications and credentials in labor markets.

Focusing on the problem regarding the need for qualified labor, there are quite a number of studies which refer to the relationship between education and economics in general and the relationship between education and employment in particular8. For instance, while programs such as Turkish Ministry of Labor and Social Security's "National Employment Strategy"9 and Turkish Ministry of National Education's "Vocational High School is a National Matter"10 emphasize the importance of adaptation between education and the labor market, they also emphasize that this is becoming increasingly difficult. Undoubtedly, it can be argued that the changes in the structure of production and business organization are effective in the global economic order mentioned above.

An important part of the market's recommendations for overcoming the aforementioned difficulty is shaped around the concept of qualification. Qualification refers to having the ability to do certain work packages that are not directly related to work such as basic knowledge, skill and predisposition regarding a profession. The market now demands vocational qualifications from job seekers instead of vocational knowledge and skills because vocational skills solely are not sufficient for the rapidly increasing jobs whose structures are also rapidly changing. For this reason, the entire global labor market has set a vocational qualifications framework with a new strategy, and encourages countries to adapt their own education systems with these aforementioned qualifications. Indeed, Turkey has been making adjustments according to the European Qualifications Frameworks within the context of the European Union (EU) membership process.

Regardless of the appropriateness of the relevant efforts or whether or not they solve the problems, unemployment seems to inevitable, at least in the short term, from the perspective of job seekers because the recommendations contain at least medium-term solutions. As a matter of fact, the analysis done in "Key Indicators of the Labour Market" by the International Labour Organization (ILO) 11 using education and labor market data sought the answer to the question whether individuals with higher education levels really face lower unemployment risk in the labor market as predicted by theories. According to the findings of the ILO survey, the education level of the workforce has increased worldwide since participation to education has been increasing day by day. However, the increase in the participation level to higher education, i.e., the workforce becoming more educated, does not mean that these individuals face less unemployment. In other words, the increase in the number of individuals with university degrees does not pave the way for low unemployment at the global level.

\footnotetext{
7 Martin Carnoy, "Eğitim ve Ekonomi İlişkisi”, Ankara Üniversitesi Eğitim Bilimleri Fakültesi Dergisi. 22/1 (1983), 485-504.

8 Ministry of Labor and Social Security. "Strengthening The Relationship Between Education and Employment”, (Retrieved September 21, 2018)

9 "National Employment Strategy" (UIS), 2017

10 MLMM, Vocational High School is a National Matter, 2012 (Retrieved August 13, 2018)

11 ILO. Key indicators of The Labour Market (KILM). International Labour Office, Geneva, 2015
} 
This is clearly apparent in the case of Turkey. According to Turkish Statistical Institute data12, the number of university graduates between the 2008 and 2017 and the change in the unemployment rate increase in parallel. There is a continuous increase in the number of university graduates from 2008 to 2017. In 2008, the number of university graduates was $3,827,742$. This number increased to $10,340,326$ in 2017. In other words, the number increased 2.7 times. However, there was an increase in the number of unemployed university graduates in parallel with the increase in the number of university graduates. The rate of unemployed university graduates increased to $12.7 \%$ in 2017, which was $9.2 \%$ in 2008.

In the study titled "Key Indicators of the Labor Market Ninth Edition"13, ILO determined that individuals with university degrees had a lower risk of being unemployed in the 67 of 93 countries examined by the organization compared to the individuals with lower education levels. According to the study, mostly in high-income countries high level of education protects workers from unemployment. On the other hand, the same study presented a more complicated picture for the upper middle-income countries. In the low-income and lower middle-income economies, people tend to have higher levels of education more but face higher risk of being unemployed. The ILO explains this situation as a clear discrepancy between the number of talented people in developing economies and the number of jobs available appropriate to their qualifications and expectations. ILO reports and particularly the unemployment indicators of developing countries show that the unemployment rate of individuals with university degrees tends to increase. Increasing rapid in numbers, this group of people has begun to have difficulty in finding a job or has been able to find a job after a long time. In addition, the number of people who find jobs directly related to their education has been decreasing. For this reason, it is important to be extra careful about arguing that educated populations are employed because of their education while analyzing the related statistics. The fact that the number of wanted employees does not increase despite the increase in the educational qualifications of the job seekers can turn the job search process into a big competition for job seekers and can cause an increase in the qualifications offered by the job seekers so that they can stand out in this competition.

Job search behavior is defined as the job seekers' job search efforts. Job search behavior can also be defined as carrying out certain activities through effort and time to get information about labor market alternatives 14 explained job search behavior as the "purposive, volitional pattern of action that begins with the identification and commitment to pursuing an employment goal" by emphasizing its relationship with employment purpose. Kanfer et al.15 described the dimensions of job search behaviors as follows: Intensity-effort (frequency of the job search behavior and the effort needed), content-direction (activities engaged and the quality of these activities), temporalpersistence (persistence in job search and its dynamism).

12 Turkish Statistical Institute, Selected International Indicators (Retrieved February 04, 2019)

13 ILO. Key indicators of The Labour Market (KILM). International Labour Office, Geneva, 2016

14 Steven G. Rogelberg, Job search. Ed. Steven G. Rogelberg., Encyclopedia of Organizational Psychology (California: Sage Publications, 2007), 414

Robert D. Bretz, John W. Boudreau and Timothy A. Judge, Job Search Behavior of Employed ManagerS, Personnel Psychology 47.2 (1994), 278

Ruth Kanfer, Connie R. Wanberg, and Tracy M. Kantrowitz, Job Search and Employment: A Personality Motivational Analysis and Meta-analytic Review, Journal of Applied Psychology 86/5 (2001).

15 Kanfer, "Job search and employment: A personality motivational analysis and meta-analytic review," 
Job search behavior of individuals with different labor qualifications and profiles will be different form each other. On the other hand, it is possible that the job search behaviors of individuals who just graduated and began to search for a job and the results they will see after this process will be different than the job search behaviors of individuals who are laid off or who are looking for a new job while still being employed16. The common point between the individuals who are looking for their first jobs after graduation and the individuals who are laid off is "being unemployed". Therefore, the main reason why the individuals in both categories exhibit job search behaviors is to find an employment opportunity 17. The first time job seekers are the ones who step into business life after finishing their education. Job search processes are especially important for this group because it is highly probable that the first jobs that these individuals will be recruited for will have a large impact on their future professional careers and incomes. Increasing competition due to global mobility in both the field of education and the labor market makes job search more important for first time job seekers 18 .

The most important factor in determining the expectations of a person form life in general, and in particular, the employability and the duration of exposure to unemployment in the long term, education (others are work experience and migration) constitutes the only component of human capital while searching for job for the first time 19 . Because most of the new graduates are looking for a job for the first time, their educational qualifications appear to be the most important qualities in finding a job. High competition in labor markets forces graduates to increase their educational qualifications. The increase in the number of undergraduate, graduate and doctorate programs and the number of students in higher education can be considered as indicators of the search in question. Indeed, according to the statistics of the Council of Higher Education20, the number of individuals doing their graduate degrees was 333052 during the academic year of 2013-2014 academic year, whereas this number increased more than 1.5 times up to 549773 during the academic year of 2017-2018.

Historically, labor supply and demand was met through ways such as informal worker bazaars, public or private employment agencies, newspaper advertisements, etc. Nowadays, one of the areas that met the labor supply and demand is e-labor markets. The number of online job search web sites has been increasing both around the world and in Turkey. On the one hand, job seekers can upload their resumes to these databases after reviewing the employment opportunities and can apply for jobs. On the other hand, employers can upload the labor qualifications they want to these databases and find the workers they need. The role of job advertisements in newspapers is largely taken over by these web sites, and therefore, these job search sites became, in a sense, modern forms of the job advertisements in newspapers. This new situation can be characterized as the meeting of labor supply and demand in the virtual world. Today, using the internet-based e-labor market, businesses reach a wider market in terms of geography.

\footnotetext{
16 Rogelberg,, "Job search”, 414

17 Rogelberg, "Job search", 414

18 Cheryl D.Wilson, Predictors of Job Search Behaviour in Canadian and Australian Undergraduate Students. (Victoria: University of Victoria, Unpublished doctoral dissertation, 2007), 2.

19 Sedat, Murat and Levent Şahin, Gençlerin İstihdamı/İşsizliği Bakımından Türk Eğitim Sisteminin Değerlendirilmesi. Çalışma ve Toplum 30 (2011), 93-135.

20 YÖK (Council for Higher Education), Summary Table of Student Numbers (Retrieved February 16, 2019).
} 
This process is much cheaper and faster than the past21. Indeed, there are many advantages of the aforementioned websites compared to the human resources sections of the newspapers or other job search methods. Providing more information for more jobs without any space constraints, easier job search process, sharing of the job advertisements immediately and changing these advertisements easily are some of the advantages of these job search web sites 22. Due to these and other characteristics, the internet environment and the related sites in this environment have become one of the most preferred job search methods and tools in the world, and their popularity has increased every day23. For example, kariyer.net, one of the important job search web sites in Turkey, has resumes of more than 25 million job seekers. More than 94 thousand companies also search for the workforce they need on this same web site 24 . Similarly, another important job search engine, secretcv.com web site has 22 million resumes and 65 thousand member companies according to November 2017 numbers 25. Secretcv.com web site emphasizes that the job seekers have the opportunity to professionally manage their career through the resumes they create, and expresses that individual users do not pay any fees for membership and for the services that will be used later on. Today, the popularity of these sites has reached such high levels that job search sites have even become an excellent source of information on what kind of a structure an institution has in terms of personnel and in what areas the institution has personnel shortage 26. Therefore, these internet sites, which are called e-labor markets today, offer great opportunities as large databases in terms of labor market analysis.

This study hopes to determine the university graduates' presentation styles of their educational qualifications and strategies regarding these styles. Thus, this study also hopes to contribute to the understanding of this market's functioning and the transformation in the relationship between education and employment.

The purpose of this study is to determine the job seeking university graduates' presentation styles of their educational qualifications and strategies regarding these styles, and to analyze the relationship between job demands. In this context, another purpose of this study is to analyze whether or not job seekers' experiences, other qualifications and signs identifying themselves to the employers accompany their educational qualifications.

\section{Method}

The study employed the qualitative research method. Qualitative research allows researchers to analyze subject-specific situations in social areas27. The labor markets, the topic of this study, is an area where the subjects who are the job seekers and the

21 Dougall, 2001 cited in Ebru Güler. E-human resources management of enterprises and developments in E-employment processes, Ege Academic Review, 6.1 (2006) 17-23.

22 Muammer Sarikaya, Meltem Erdogan and F. Zisan Kara, Internet Economics and Corporate Sustainability, Eskisehir Osmangazi University Journal of Economics and Administrative Sciences 5.2 (2010), 37-38.

23 Zeki Deniz Dost, Job Search Methods in The Fight Against Unemployment and Evaluation of Turkish Employment Agency. (Republic of Turkey Ministry of Labor and Social Security, Turkish Employment Agency, Unpublished master Thesis, Ankara, 2014), 41

24 Kariyer.net, About us. (Retrieved January 18, 2018)

25 Secretcv.com, About us. (Retrieved January 18, 2018)

26 Haşim Bağc1, "Social Engineering and Surveillance", Denetişim, 1 (2016) 42-51.

27 Anselm Strauss and Juliet Corbin, Basics of Qualitative Research: Grounded Theory Procedures and Techniques, New Delhi: SAGE Publications, 1990. 
employers meet and where each subject use appropriate strategies in accordance with their own goals. In this context, it can be said that the job seekers' presentation styles of their educational qualifications in order to be considered as "appropriate" by the employers during the job search process can be interpreted within the context of subjectivity. Within the scope of this study purpose, qualitative research design was preferred since it provides important opportunities analytically.

Study data was obtained from the web site named UNIISBUL (uniisbul.com), one of the job search web sites in Turkey. First, in order to collect the study data, the necessary permission was obtained from the aforementioned website. The study data was collected between the dates of 01.11.2018 and 29.11.2018 by using purposive sampling technique. The resumes of job seekers looking for jobs in İstanbul, the most populous and developed city in Turkey, were included in the study since it was believed that the professional diversity of the job seekers would be more seen. The resumes were chosen amongst the ones looking for jobs in the service, production (industry) and information sectors with at least undergraduate degrees. Thus, the study tried to understand the characteristics the job seekers looking for jobs in different fields brought to the fore during the job searching process. Furthermore, the resumes belonging to an equal number of women and men were analyzed. In this context, the study group consisted of a total of 90 resumes belonging to 16 males and 19 females looking for jobs in the service sector, 16 males and 18 females looking for jobs in the information sector, and 16 males and 19 females looking for jobs in the industry sector. The UNIISBUL site had organized an e-form for job seekers to present their personal and professional qualifications along with some personal information. In a sense, this form can be considered as a CV/resume of the job seekers. Those who login to this site as job seekers write or mark their own information on the relevant sections in the information form. The e-form on the UNIISBUL web site includes headings like personal information, language information, education level, work experience, job preference information, work style, certificates, club/association memberships, hobbies, awards, top 10 characteristics, day and book. In the form, there are many headings from job seekers' personal information to which books they read. In other words, employers do not only accept job seekers who are appropriate for the jobs but also look at many signs defining the social, political and similar aspects of the job seekers.

The data was analyzed using qualitative research methods, specifically descriptive analysis and content analysis methods. Descriptive analysis provides the researchers with an overview of the current situation and allows them to see the whole picture 28 . In this study, the examined qualifications in the resumes belonging to the individuals seeking employment were tabulated. This allowed researchers to see the whole situation about the job seekers. The data was analyzed by content analysis in accordance in line with the study purpose. Content analysis is the analysis of data according to certain classifications29. The data was analyzed according to the job seekers' efforts to match themselves with the employee demands, the presentation styles of their educational qualification in their resumes, their work experience, the certificates they had, the jobs they listed as they can do, their preferences regarding their work times and their presentation styles of their other qualifications.

28 Ali Yıldırım and Hasan Şimşek, Qualitative Research Methods in The Social Sciences. Ankara: Seçkin Yayınlar1, 2003.

29 David, Silverman, Interpreting Qualitative Data: Methods For Analysing Talk, Text and Interaction. London: SAGE Publication, 2001. 
Quantification of data was avoided as much as possible during the data analysis as a requirement of the qualitative research approach. Rather, in the study, an analysis regarding the subjectivities of the individuals was done by revealing the different tendencies shown by the individuals in their job search behaviors. Therefore, certain examples regarding different attitudes presented in individuals' job search behaviors were tabulated in order for the readers to see the examples better. However, quantification was avoided in the tables.

\section{Findings}

\subsection{Educational presentation styles of job seekers}

Increasing the effectiveness of job search behavior is one of the important factors accelerating the job search process of job seekers. The most important point that determining the effective job search behavior is to match the qualifications of the job seekers with the qualifications desired by the employer. Educational qualifications have importance amongst the qualifications of job seekers. In this case, the educational qualifications of the job seekers and the job seekers' presentation of their educational qualifications gain importance.

In the resumes making up the study group, the resume holders presented their education levels in several different ways. Some, for example, stated their undergraduate degrees, while others preferred also to present their associate degrees. This attitude can be attributed to job seekers' strategy to address different job alternatives during the job search process and thereby increase their chances of finding a job. Individuals presented their educational qualifications in their resumes as shown in the table below:

Table 1. Presentation Styles of Education

\begin{tabular}{lcc}
\hline Presentation Styles of Education & F & $\%$ \\
\hline Undergraduate degree & 73 & 64,0 \\
Associate degree + Undergraduate degree & 13 & 11,4 \\
Associate degree + two undergraduate degrees & 1 & 0,9 \\
Two undergraduate degrees & 9 & 7,9 \\
Undergraduate degree + Two associate degrees + & 1 & 0,9 \\
Master degree & & 0,9 \\
Associate degree + Undergraduate degree + & 1 & 13,0 \\
Master degree & & 0,9 \\
Undergraduate degree + Master degree & 15 & 100,0 \\
Master degree & 1 & 114 \\
Total & & \\
\hline
\end{tabular}

As seen in Table 1, job seekers had eight different education levels. Most of them had degrees at the undergraduate $(64 \%)$ level. This is followed by undergraduate + master degree $(13 \%)$, associate degree + license $(11.4 \%)$ and two undergraduate programs 
(7.9\%). The increasing competitive nature of the job search process might lead individuals to increase their education level in order to increase their chances of finding a job in the labor market. For example, the resume analysis revealed that individuals did undergraduate degrees on top of their associate degrees, did another undergraduate degree on top of their undergraduate degrees or is master degrees on top of their already existing degrees. This is an indication that in the process of finding employment in a world where higher education became common, education is considered for job seekers a means of getting ahead in the job search competition. One of the remarkable points of the findings in Table 1 is that the individuals with master degrees included their associate degrees on their resumes even though their education levels were already high. In other words, some candidates have chosen the way to make themselves visible by presenting all of their educational degrees regardless of the high level of education they received. This can be associated with the efforts of some candidates to strengthen others' perception of themselves of having a higher quality education providing more information in the education level section. On the other hand, the same situation can be associated with the fact that an individual with a master degree may accept two employment opportunities by providing their master degree and associate degree. Both females and males believed that education would give them an advantage in the job finding competition.

Another point regarding how job seekers present their educational qualifications is which job application-jobs they matched their education levels with. In other words, the existence or absence of a relationship between the jobs the job seekers applied to and the types and levels of education they had is particularly meaningful for the interpretation of the relationship between education and employment. In the study, several different matters regarding the aforementioned relationship were determined. The following table shows the relationship between education and job choices in the selected advertisements:

Table 2. Examples Regarding Education Levels and Job Preferences

\begin{tabular}{|c|c|c|}
\hline Education & Field & Job Preference \\
\hline \multirow[t]{2}{*}{$\begin{array}{l}\text { Undergraduate } \\
\text { degree }\end{array}$} & $\begin{array}{l}\text { Mechanical } \\
\text { Engineering }\end{array}$ & $\begin{array}{l}\text { Elevator Preliminary Design Project Development, } \\
\text { Elevator Engineering Authorization, Construction } \\
\text { Supervisor }\end{array}$ \\
\hline & History Teaching & $\begin{array}{l}\text { Human Resources Assistant, Social Studies Teacher, } \\
\text { History Teacher }\end{array}$ \\
\hline \multirow{3}{*}{$\begin{array}{l}\text { Associate } \\
\text { degree }+ \\
\text { undergraduate } \\
\text { degree }\end{array}$} & $\begin{array}{l}\text { Radio, Television } \\
\text { and Cinema, }\end{array}$ & $\begin{array}{l}\text { Agency Personnel, Ticket Sales Personnel, Office } \\
\text { Personnel, Distribution Personnel, Warehouse Inventory }\end{array}$ \\
\hline & $\begin{array}{l}\text { Public } \\
\text { Administration }\end{array}$ & $\begin{array}{l}\text { Personnel, Teller, News reporter, Office Personnel, } \\
\text { Booth Personnel, Data Entry personnel, Host, Poll } \\
\text { Taker, Wait staff, TV Show Actor, General, Actor }\end{array}$ \\
\hline & $\begin{array}{l}\text { Construction } \\
\text { technology, } \\
\text { Architecture }\end{array}$ & $\begin{array}{l}\text { Construction Personnel, Civil Engineer, Architecture, } \\
\text { Technician }\end{array}$ \\
\hline
\end{tabular}


Sociology,

Nutrition

Dietetics
Expo Hostess, Volunteer Educator, Store Personnel, and Play Sister, Poll Taker, Wait Staff, Photographer

Two

undergraduate

degrees

Computer

Engineering,

Industrial

Engineering

Analysist Software Developer, Computer Engineer, Financial Analysist, Oracle Software Specialist, Project Personnel, Database Counselling/Development Specialist/Programmer, Software Engineer/Supervisor/ Implementation Specialist

Undergraduate Statistics degree $\quad+$ Master degree
Analysist Software Developer, Financial Analysist, Financial Analysist Specialist Assistant, Financial Reporting Specialist, Reporting Personnel, Database Development Specialist, Database Specialist

Architecture, Office Personnel

Occupational

Health and Safety

The relationship between the job seekers' education and the job positions they stated they can work in can also be affected by their perception of what they can do with their education. When their resumes are examined, it was determined that the majority of the job positions of those who provided only their undergraduate degree were directly related to their degrees, whereas the job positions job seekers who provided both their associate degrees and undergraduate degrees showed diversification. Table 2 presents some examples showing the related tendencies reflected in the individuals' resumes.

As can be seen from the examples presented in Table 2, most of the jobs the undergraduate degree owners claimed they could work in were job areas generally related directly to their education. For example, while individuals who graduated from the department of History Teaching stated that they could work as history or social studies teachers, individuals who graduated from the department of Mechanical Engineering stated that they could work in job positions such as "Elevator Preliminary Design Project Development" and "Elevator Engineering Authorization" and that they could work as construction supervisors, one of the first job positions engineers can work in. On the other hand, as can be seen from the examples presented in Table 2 regarding job seekers with both associate and undergraduate degrees, these individuals stated that they could work in more different job positions. Amongst this group, attitudes towards different jobs preferences attract notice. For example, the graduates of departments from different social science fields (Radio, Television and Cinema, Public Administration) stated that they could work in job positions that were not directly related to their education such as agency personnel, ticket sales personnel, office personnel, distribution personnel, warehouse inventory personnel and teller and in job positions they were directly related to their education such as news reporting which require qualification. 
On the other hand, job seekers who graduated from Construction Technology and Architecture preferred different job positions more directly related to their education which are not that flexible such as Construction Personnel, Civil Engineer, Architect and Technician.

A job seeker who had provided two different undergraduate degrees in her resume, one from a social sciences and one from health sciences, applied for job positions such as expo hostess, volunteer educator, store personnel, play sister, poll taker, wait staff and photographer, which were not compatible with her degrees. On the other hand, another job seeker, who graduated from Computer Engineering and Industrial Engineering, preferred jobs that were directly related to his degrees and that were defined as specialist positions.

Amongst the job seekers with both undergraduate degrees and master degrees, a job seeker who graduated from the Department of Statistics applied to recognized job positions of the sector such as Analyst Software Developer, Financial Analyst, Financial Analyst Specialist Assistant, Financial Reporting Specialist, Reporting Personnel, Database Development Specialist and Database Specialist, which were all directly related to the individual's degrees stated that the sector has aspired to good positions. On the other hand, another job seeker with Architecture and Occupational Health and Safety degrees was willing to work as office personnel.

Undoubtedly, many factors such as the individuals' professional qualifications or their perceptions regarding these qualifications, their psychologies, private lives and future plans are effective in all of the education degrees and job preference matching presented above. The above examples, however, can be interpreted as data that might problematize the Human Capital Theory (HCT). Indeed, HCT argues that the individuals will be employed since their education levels will provide them with qualifications in the jobs related to their education, and thus the theory establishes a direct relationship between education and employment. In this context, according to the majority of the resume holders examined in this study, especially according to the candidates with disadvantages such as not having high education levels, not graduating from good universities or not having work experience, HCT was not valid. In many resumes examined, the fact that the resume holders stated that they can work in jobs unrelated to their education suggests that the candidates might not be especially very selective in the jobs they would prefer to work in today's conditions where finding employment is increasingly difficult. In this context, the findings also revealed that employment should not only be associated with educational content or educational level, but also be associated with macro-social conditions affecting labor markets.

\subsection{The relationship between work experience and job search behavior}

Nowadays, the increasing progress in technology every day and the integration of technology into many jobs rapidly change job styles and therefore the qualifications required for these jobs. Hence, these rapidly changing job styles in business life alienate employees to their educational lives. Indeed, the vocational skills that individuals learn throughout their educational lives are mostly related to general skills rather than specific qualifications regarding the related vocations. In other words, the related qualifications cover knowledge, skills and other qualifications related to the sector. In fact, sectoral jobs are now increasingly atomized. On the other hand, labor demands are focused on individuals who have the qualifications to complete work packages. For example, in the IT sector, the field of software is highly complex and atomized. In other words, this field contains many jobs within itself. However, employers will prefer to make their 
decisions while choosing new employees amongst the ones from those who can do the software unit work packages. This further highlights the importance of presenting work experience in job search behavior. On the other hand, it is possible to argue that the importance of work experience will increase in getting ahead in finding employment, especially in conditions where the effect of individuals' education levels and their universities lost their importance compared to the past as stated earlier. In this respect, the present study also preferred to examine job seekers' work experiences stated in their resumes. The following table shows the distribution of job seekers' work experiences:

Table 3. Distribution Regarding Job Seekers' Work Experience

\begin{tabular}{lcr}
\hline Work Experience & $\mathrm{f}$ & $\%$ \\
\hline None/Not stated & 31 & 27,2 \\
1month-1 year & 28 & 24,6 \\
$1-5$ years & 42 & 36,8 \\
5-10 years & 11 & 9,6 \\
$10+$ & 2 & 1,8 \\
Total & 114 & 100,0 \\
\hline
\end{tabular}

As seen in Table 3, a significant proportion of job seekers $(27,2 \%)$ were new graduates and therefore did not specify any working experience. Therefore, the effort to present the acquired work experience in the resumes is more interpretable especially in terms of individuals who provided their work experiences. When the resumes were examined, it was noted that there were individuals who presented their one-month internship as work experience and who presented their jobs as waiter or busboy as work experience even though they were computer engineers. In particular, it is apparent that the effort to show the work experience in job search advertisements is reflected in the job search behavior. The individuals with the most experience who also presented their experience in their resumes were the ones with experience between one and five years. It can be argued that those with more work experience, i.e. between five and ten and more than 10 years are seen less frequently in job search advertisements.

Whether work experience has an effect on the work preferences of employees is significant in terms of interpreting the relationship between work experience and job search behavior. In this regard, the resumes revealed that resume holders' job preferences were directed towards a narrower and specific field in parallel with the increase in their work experience. Table 4 presents some examples regarding the attitudes of the owners of the examined resumes. 
Table 4. Examples Regarding the Relationship between Work Experience and Job Preference

\begin{tabular}{|c|c|c|c|}
\hline Field & Work Experience & $\begin{array}{l}\text { Work } \\
\text { Experience } \\
\text { (year) }\end{array}$ & Work Preference \\
\hline $\begin{array}{l}\text { Computer } \\
\text { Engineering }\end{array}$ & - & - & Computer Engineer \\
\hline $\begin{array}{l}\text { Computer } \\
\text { Engineer }\end{array}$ & $\begin{array}{l}\text { Mostly Intern and } \\
\text { Worker }\end{array}$ & $\begin{array}{l}\text { Less than } 1 \\
\text { year }\end{array}$ & $\begin{array}{l}\text { IT Specialist, Computer Engineer } \\
\text { System and Network Personnel, } \\
\text { Data Entry Personnel, Software } \\
\text { development } \\
\text { Software Intern }\end{array}$ \\
\hline $\begin{array}{l}\text { Computer, } \\
\text { Computer } \\
\text { Engineering }\end{array}$ & $\begin{array}{l}\text { Software Support } \\
\text { Specialist, Call center } \\
\text { Specialist }\end{array}$ & $\begin{array}{l}2 \text { Years } 1 \\
\text { month }\end{array}$ & $\begin{array}{lll}\text { Software Controller, } & \text { Software } \\
\text { Support Personnel, } & \text { Software } \\
\text { Support Manager, Software Intern }\end{array}$ \\
\hline $\begin{array}{l}\text { Political Science } \\
\text { and International } \\
\text { Relations, } \\
\text { International } \\
\text { relations Master } \\
\text { Degree }\end{array}$ & $\begin{array}{l}\text { Buying Specialist, } \\
\text { Research Intern, } \\
\text { Immigrant Specialist, } \\
\text { Animator, Field } \\
\text { personnel, Editor, } \\
\text { Cashier, Translator }\end{array}$ & $\begin{array}{l}5 \text { years } 2 \\
\text { months }\end{array}$ & $\begin{array}{l}\text { Education Assistant, } \\
\text { Administrative Affairs Assistant, } \\
\text { Manager Candidate, Translator, } \\
\text { Editor, Civil Society Personnel }\end{array}$ \\
\hline $\begin{array}{l}\text { Control } \\
\text { Engineering }\end{array}$ & $\begin{array}{l}\text { Software Support } \\
\text { Specialist Assistant, } \\
\text { Private Tutor, Play } \\
\text { Sister }\end{array}$ & $\begin{array}{l}12 \text { years } 10 \\
\text { months }\end{array}$ & $\begin{array}{l}\text { Software Test Engineer, Software } \\
\text { Test Specialist }\end{array}$ \\
\hline
\end{tabular}

As can be seen from some of the examples presented in Table 4, the work preferences became more specific as the work experience increased. For example, a computer engineer who has no experience outside internship stated computer engineering directly, while experienced computer engineers listed some specific positions in the field of informatics amongst their job preferences. Also, a computer engineer with a two years and two months of experience as Software Support Specialist and Call Center Personnel preferred jobs such as Software Controller, Software Support Personnel, Software Support Manger and Software Intern. These jobs, of course, are both career providing and high-income providing jobs for the engineer over time. On the other hand, while the fact that the occupational positions become more specialized rather than generalized can have a decreasing effect on job finding opportunities sue to the narrowing of the job field, it can also have an increasing effect on recruiting prospects of the job seekers since the employers can interpret this as the job seekers being more selective, experienced and knowledgeable and therefore more qualified. Therefore, it is possible to argue that in addition to the job seekers' vocational qualifications, employers' interpretation styles regarding the job seekers' presentation of these qualifications might shape the processes related to job search behavior. 


\subsection{Signs for the Employer}

The increasing complexity of the production process in many jobs in business makes it even more important for the employers to employ the right personnel in their own institutions. In fact, recruiting inappropriate candidates mean both time and financial loss for employers. As the findings presented so far demonstrate, although employability is interpreted to a great extent through educational qualifications, many variables, as well as relevant qualifications, affect employability. Some of these variables might be directly related to the qualifications required by the jobs, while others might also be related to some personal qualifications other than those required by the jobs. In the UNIIISBUL.com site, the web site examined within the scope of the present study, the employers wanted the job seekers to list certain individual characteristics in their resumes in addition to their educational qualifications and work experience. In this context, the site lists a total of 21 individual characteristics and the job seekers are asked to select their best ten characteristics amongst these 21 characteristics. In this regard, the related characteristics become the markers that help the employers determine the candidates they will recruit. The 21 characteristics included in the form are active listening, analysis, science, observation, persuasion, quality control, decision making, complex problem solving, talking, coordination, critical thinking, setup, math, negotiation, learning, programming, system analysis, promotion, technology design, writing and time management. The following graph presents the total scores of the ten best characteristics of the job trainees.

Graph 1. Distribution Regarding the Ten Best Characteristics

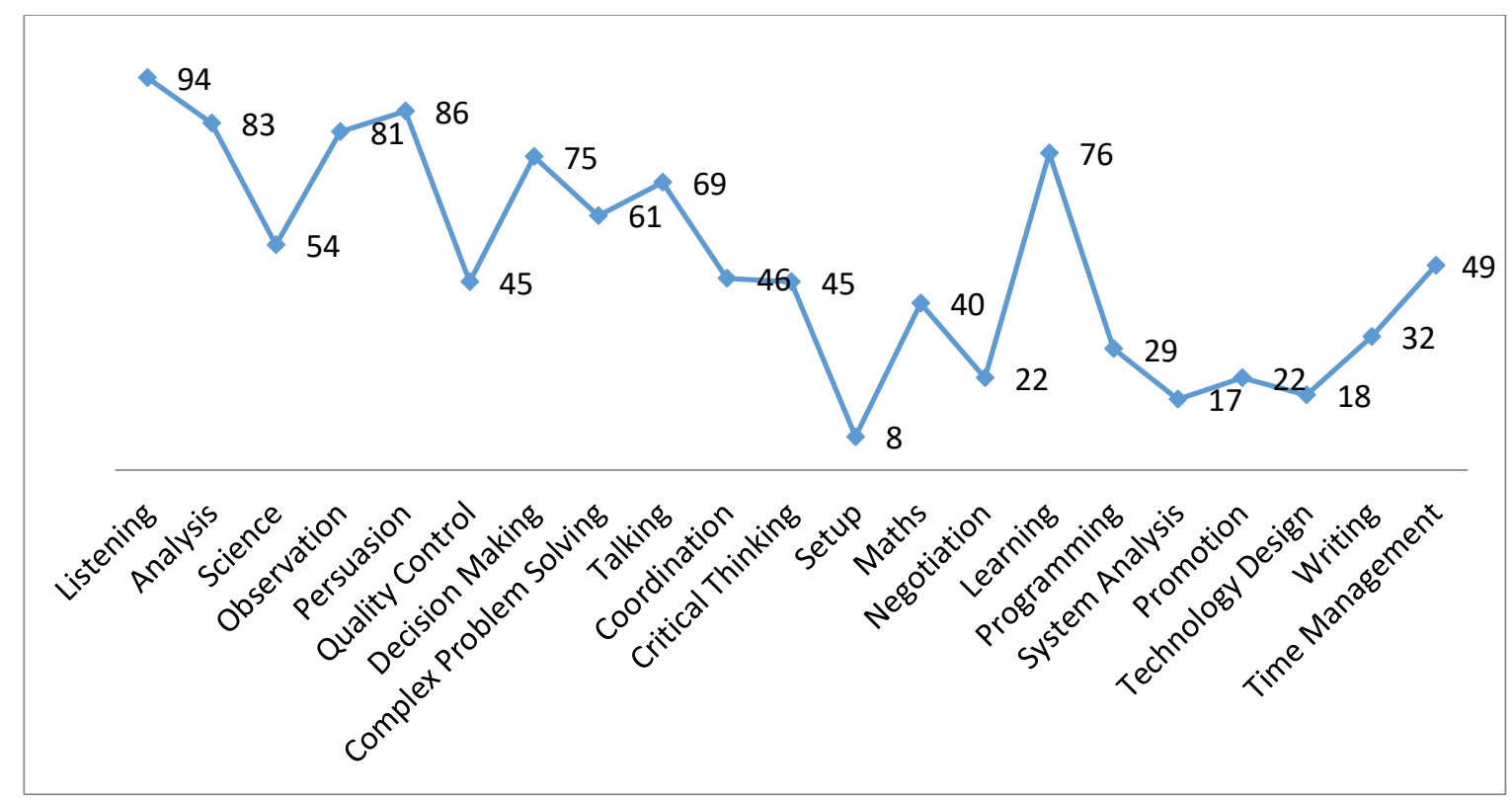

As shown in Graph 1, the most listed four characteristics amongst the job seekers' ten best individual characteristics were active listening $(\mathrm{f}=96)$, persuasion $(\mathrm{f}=86)$, analysis $(\mathrm{f}=83)$ and observation $(\mathrm{f}=81)$. On the other hand, the least listed four characteristics were setup ( $\mathrm{f}=8)$, system analysis $(\mathrm{f}=17)$, technology design $(\mathrm{f}=18)$ and promotion $(\mathrm{f}=22)$. Despite the existence of 26 engineers amongst the resumes and despite the fact that many of these engineers took courses related to computer technology, technological characteristics such as setup, technology design and system analysis were listed the least. This can be explained by the fact that resume holders had little work experience. Interestingly, the most listed characteristics are not directly associated with vocational qualifications but are associated with individual characteristics. However, surprisingly, 
the least listed characteristics are characteristics that might be associated with vocational characteristics. In a sense, the job seekers try to give a sign to the employers that they would easily attain the qualifications they do not have by stating that have the vocational qualifications such as active listening, observation, analysis and persuasion. Thus, job seekers promise that they can easily close their shortcomings between the rapidly changing qualifications of production processes and the education they have. On the other hand, job seekers also state that they can do every job with their good characteristics and, if necessary, they can also work as intermediate worker.

The other markers provided to the employers by the job seekers were the books read, association memberships, certificates and attended courses. Some of the resume holders listed the books they have read and the association memberships they had in their resumes. Undoubtedly, both of these markers showed the job seekers' social and political tendencies. Some job seekers tried to increase their recruitment chances by the employers who paid attention to these characteristics. Other important markers were the courses attended by the job seekers and the certificated related to these courses. While most of these courses were related to computer technology, some of them were in other areas from diction to chess. The job seekers have high perception about believing that having a diploma and certificates are important makers for employment. As a strategy, some job seekers tried to increase their chances by presenting more certificates.

\section{CONCLUSION}

The relationship between knowledge and skills acquired by education and the labor qualifications required by the market during the period of industrial society where more direct relationships were established was explained with Human Capital Theory 30. According to the Human Capital theory, people were employed in jobs appropriate to the education they received. An engineer used to work as an engineer, and a journalist used to work as a journalist. With the diversification of economic relationships and the development of open economies, the labor qualifications the market required have changed accordingly. In the new economic order, jobs gradually gained new dimensions and were divided. Naturally, the required labor qualifications also gained a new form in accordance with the increasingly undefined jobs. Therefore, since universities were not able to catch up with the pace of the market, the qualifications gained at universities turned into general qualifications. Related developments have led to further complication in the relationship between education and employment. These developments naturally led to the introduction of new theories such as the Queue and Screening Hypotheses to explain the relationship between the education and employment relationship and the relationship between employment and individuals' qualifications. Contrary to the Human Capital Theory, these theories claim that the relationship between education and employment is not that linear. In other words, educational qualifications can be interpreted as markers indicating the individuals' appropriateness and tendencies towards a certain job31. The present study's results determined that the Human Capital Theory was problematic in terms of the data discussed in the study. On the other hand, the related results showed that the Queue and

30 Theodore W. Schultz, "Investment in Human Capital." The American Economic Review, 1/17 (1968), $22-23$

Muhsin Hesapcığlu, Management and Politics of Human Resources. (İstanbul: Beta Basım Yayım Dağıtım, 1994), 404-409

31 Ünal, Eğitim ve Yetiştirme Ekonomisi, 123 
Screening Hypotheses can be more functional in explaining the relationship between education and employment. Other studies on this issue support this result. For example, in the study of Beltekin32, which examines the relationship between labor and education, it is seen that employers exhibit a similar behavior. In this study, the relationship between the manpower qualifications sought by employers and their education turned out to be a more indirect relationship. In the field survey conducted by Beltekin, Çete, Acay and Akan33, it was found that employers did not prefer vocational high school graduates as intermediate staff. Instead, they prefer to train unskilled employees at work.

Some of the other study results are as follows: Candidates, who want to be employed exhibited the tendency to list all the education degrees they have completed, rather than only stating the most recent level of education. In this regard, it was determined that some candidates cared about the perception that the education they had would create on the employer rather than the content or level of education. In other words, some candidates tried to strengthen the perception that they had received a more qualified education by providing more educational information in the related section of their resumes.

Another study result put forth that there was no one-to-one alignment between the education of the candidates and the jobs they stated that they could apply and work at. Within this scope, certain variables such as the universities where the candidates graduated from and whether they had work experience or not can be considered as effective factors in candidates' attitudes. In fact, it is normal for the candidates who consider themselves having strong qualifications in the negotiation table with the employers to be more selective about the jobs they apply for. On the other hand, another variable that can considered as effective in the related attitude is the macro-structural conditions in the sector where the candidates have completed their education. For example, candidates who have graduated from an area with low employment opportunities may not be very selective in terms of employment. Hence, it can be argued that the education economics theories which explain employment mostly through education should be questioned. In fact, employment is not only an individual relationship between the employer and the job seeker who wants to find a job, but it is also a social phenomenon shaped by macro socioeconomic and political conditions determining this relationship.

One of the most important criticisms of the linear relationship between education and employment is that the labor markets are not rational, like Human Capital Theory assumes, and that any power relationship existing in the society also exists in the labor market. Another criticism that can be considered in this context is that job-related technical skills are over-focused in the qualifications required for employability. According to these criticisms, although employers care about the technical skills required by their jobs, they also pay attention to some personality traits such as being docile, punctual, obedient, and easy to learn.

32 Nurettin Beltekin, İşgücü Talebi ve Eğitim Ilişkisi Üzerine Bir Analiz (İş İlanları Örneği). Electronic Journal of Social Sciences, 13/51 (2004)

33 Nurettin Beltekin, Ufuk Çete, Ömer Acay and Mahmut Akan, (2016). Sosyal ve iktisadi kalkınma için meslek lisesi mezunlarının istihdamı -Mardin örneği- (ÜNIDAP Uluslararasi Bölgesel Kalkinma Konferansi Bildiriler Kitabi, 2016), 2. Cilt, 2-12 
As a result of the present study, some conclusions have been reached supporting these related criticisms. The resume holders emphasized the most the qualifications that were not related to any specific job such as active listening, persuasion, analysis, and observation skills, whereas some resume holders emphasized technical skills such as setup, system analysis and technology design, even though these skills were emphasized the least. Therefore, job seekers gave a certain message to the employers that they can easily learn and are humanly compatible even if they do not know everything.

The relationship between education and employment has been one of the issues frequently addressed in the second half of the 1900s. In this context, the educational economics theories and the emergence of the discipline of educational economics are largely not independent of the related investigation. On the other hand, educational economics theories, such as Human Capital Theory based on the assumptions of neoclassical economics, present the labor market as a rational individual relationship between employer and employee that is free from power relationships. In a sense, these theories serve as an ideological function to show that problems in the labor force market are not caused by the market itself. Thus, critically examining the related theories in the case of Turkey will be a meaningful in terms of reality. In this regard, it would be meaningful to include the labor markets and the macro-structural conditions that shape it into the analysis conducted on the phenomenon of employment.

\section{REFERENCES}

Bağc1, Haşim. Social engineering and surveillance. Denetişim, 1(2016), 42-51

Beltekin, Nurettin. İşgücü talebi ve eğitim ilişkisi üzerine bir analiz (İş ilanları örneği). Electronic Journal of Social Sciences, 13/51(2014)

Beltekin, Nurettin et al, Sosyal ve iktisadi kalkınma için meslek lisesi mezunlarının istihdamı -Mardin örneği-ÜNIDAP Uluslararasi Bölgesel Kalkinma Konferansi Bildiriler Kitabi 2. Cilt, 2-12

Bretz, Robert D. et al, "Job Search Behavior of Employed Managers", Personnel Psychology, 47/2 (1994), 278

Carnoy, Martin, Eğitim ve Ekonomi İlişkisi, (Translator: Nejla Tural). Ankara Üniversitesi Eğitim Bilimleri Fakültesi Dergisi. 22/1 (1983), 485-504

Dost, Zeki Deniz, Job Search Methods in The Fight Against Unemployment and Evaluation of Turkish Employment Agency. Republic of Turkey Ministry of Labor and Social Security, Turkish Employment Agency, Unpublished master Thesis, Ankara, 2014

Güler, Ebru, E-Human Resources Management of Enterprises and Developments in EEmployment Processes. Ege Academic Review, 6 (2006), 17-23

Hesapcioğlu, Muhsin, Management and Politics of Human Resources. İstanbul: Beta Basım Yayım Dağıtım, 1994

ILO, Key Indicators of The Labour Market (KILM), International Labour Office, Geneva, 2016

ILO, Key Indicators of The Labour Market (KILM), International Labour Office, Geneva, 2015 
Kanfer, Ruth et al, Job Search and Employment: A Personality Motivational Analysis and Meta-Analytic Review. Journal of Applied Psychology 86/5(2001), 837-855. https://doi.org/10.1037/0021-9010.86.5.837

Kariyer.net, "About Us", Retrieved January 18 2018, https://www.Kariyer.net/ kurumsal/hakkimizda

Ministry of Development, "Public Investments -Sector and Sub Sector Distribution", Retrieved December 12 2018, fhttp://www3.kalkinma.gov.tr/PortalDesign/ PortalControls/WebContentGosterim. aspx ?Enc=51C9D1B02086EAFB809B179F2C69 $80 \mathrm{D}$

Ministry of Labor and Social Security, "Strengthening The Relationship Between Education and Employment", Retrieved September 21, 2018, http://www.uis.gov.tr /TemelPolitikaEksenleri/EIIG

MLMM, Vocational High School Is A National Matter. Retrieved August 13, 2018, www.mesleklisesimemleketmeselesi.com/tr-TR/

Murat, Sedat et al, Gençlerin İstihdamı/İşsizliği Bakımından Türk Eğitim Sisteminin Değerlendirilmesi, Çalışma ve Toplum, 30 (2011), 93-135

National Employment Strategy (UIS), National Employment Strategy, Retrieved May $22 \quad 2018$, www.uis.gov.tr/media/1431/eg-itim-i-stihdam-ilis-kisinin-gu-clendirilmesi_is-\%25C4\%25B11-kurnaz_23-24eylu-l-c-al\%25C4\%25B1stay\%25C4\%25B1-sonras \%25C4\%25B 1 -revize. $d o c x+\& c d=9 \& \mathrm{hl}=\operatorname{tr} \& \mathrm{ct}=\mathrm{clnk} \& \mathrm{gl}=\mathrm{tr}$

Sarıkaya, Muharrem et al (). Internet economics and corporate sustainability. Eskişehir Osmangazi University Journal of Economics and Administrative Sciences, 5/2 (2010): $31-50$

Schumpeter, Joseph Alios, Capitalism, Socialism and Democracy. 1st Edition, London: Routledge, 2010

Secretcv.com, “About Us" Retrieved January 18 2018, https://www.secretcv.com/ kurumsal/hakkimizda

Silverman, David, Interpreting Qualitative Data: Methods For Analysing Talk, Text And Interaction. London: SAGE Publication, 2001

Strauss, Aaselm, Basics of Qualitative Research: Grounded Theory Procedures and Techniques. New Delhi: SAGE Publications, 1990

Psacharopoulos, George, İnsan Sermayesi Kuramı Üzerine Kavramlar ve Karmaşalar. (Translator: Pervin Nadim). M. ̈̈. Atatürk Ĕ̆itim Fakültesi Eğitim Bilimleri Dergisi. 6(1994), 217-221

Rogelberg, Steven. G., "Job Search", Encyclopedia of organizational psychology, Ed. Steven. G Rogelberg, 414-416, California: Sage Publications, 2007

Turkish Vocational Qualifications Authority, "Sector List", Retrieved January 18 2019, https://www.myk.gov.tr/index.php/en/ulusal-meslek-standard/182

Turkish Statistical Institute, "Selected International Indicators", Retrieved February 04 2019, https://biruni.tuik.gov.tr/secilmisgostergeler/sorguSayfa.do?target=tablo

Ünal, L. Işı1, Ĕğitim ve Yetiştirme Ekonomisi. Ankara: Epar Yayınları, 1996 
Wilson, Cheryl D., Predictors of Job Search Behaviour in Canadian and Australian Undergraduate Students. Victoria: University of Victoria, Unpublished Doctoral Dissertation, 2007

Y1ldırım, Ali et al, Qualitative Research Methods in The Social Sciences. Ankara: Seçkin Yayınları, 2003

YÖK (Council for Higher Education), Summary Table of Student Numbers. Retrieved February 16 2019, https://istatistik.yok.gov.tr/ 